\title{
Erratum to: The Science of Stapling and Leaks
}

\author{
Randal S. Baker • James Foote • Paul Kemmeter • \\ Randall Brady • Todd Vroegop • Matt Serveld
}

Published online: 25 September 2013

(C) Springer Science+Business Media New York 2013

Erratum to: Obes Surg (2004) 14:1290-1298

DOI $10.1381 / 0960892042583888$

In the article section titled "Stapling biomechanics," the measurement $8 \mathrm{~g} / \mathrm{m}^{2}$ is incorrect. The correct measurement should be $8 \mathrm{~g} / \mathrm{mm}^{2}$.

The online version of the original article can be found at http://dx.doi.org/ $10.1381 / 0960892042583888$.

R. S. Baker $(\bowtie) \cdot$ J. Foote $\cdot$ P. Kemmeter · R. Brady · T. Vroegop • M. Serveld

Michigan Medical Center for Health Excellence, 4100 Lake Drive SE, Suite B01, Grand Rapids, MI 49546, USA

e-mail: rbaker@mmpc.com 